\title{
Profitability and Water Productivity of Small Scale Irrigation Schemes in Northern Ghana
}

\author{
Belinda Prekoh Bruce ${ }^{1}$, Abdul-Rauf Malimanga Alhassan ${ }^{2,3}$, Xuecheng Dou ${ }^{1} \&$ Daxin Gong ${ }^{1}$ \\ ${ }^{1}$ College of Finance and Economics, Gansu Agricultural Universty, Lanzhou, Gansu Province, China \\ ${ }^{2}$ College of Forestry, Gansu Agricultural University, Lanzhou, Gansu Province, China \\ ${ }^{3}$ Ministry of Food and Agriculture, Northern Region, Tamale, Ghana \\ Correspondence: Xuecheng Dou, Gansu Agricultural Universty, College of Finance and economics, Anning \\ District, 730070, Lanzhou, Gansu Province, China. Tel: 86-138-9310-1197. E-mail: 189274901@qq.com
}

Received: November 20, 2018

Accepted: December 21, 2018 Online Published: February 15, 2019

doi:10.5539/jas.v11n3p22

URL: https://doi.org/10.5539/jas.v11n3p22

The research is financed by the Department of Science and Technology of Gansu Province, China (1504NKCA029).

\begin{abstract}
The Savelugu-Nanton District of Northern Ghana is a beneficiary of irrigation projects mostly on small scale basis schemes. Poor data situation due to inadequate appraisal of these schemes results in difficulty to track their progress and impacts, which threatens their sustainability. This study was conducted to assess the profitability and productivity of the Libga and Bunglung small scale irrigation schemes in the District between 2013 and 2015. Sixty households were selected using random sampling techniques. Production data, costs, yield and soil data were gathered using structured questionnaires and field measurements. Data on traditional rainfed systems were gathered from secondary information. The results indicated that yields of rice were greater in Bunglung than in Libga scheme but both schemes had greater yields than rainfed systems, resulting in greater profits under irrigation. However, yields of pepper were greater in Libga than in Bunglung. Crop water productivity (CWP) in terms of harvested weight of rice was 0.50 and 0.58 kilogram per cubic meter in Libga and Bunglung respectively while CWPs in terms of gross value of harvested rice were 0.38 and 0.41 Ghana cedis per cubic meter respectively. For pepper, the CWPs were 0.74 and 0.64 kilogram per cubic meter in terms of crop weight in Libga and Bunglung respectively while CWPs in terms of gross value were 1.23 and 1.07 Ghana cedis per cubic meter respectively. Irrigation improved farmers' incomes, however, pepper production was more profitable than rice production at both schemes. More investments by farmers are important to achieving maximum yields.
\end{abstract}

Keywords: irrigation, income, water productivity, revenue

\section{Introduction}

Agriculture plays a key role in poverty reduction and rural development. In Sub-Saharan Africa the number of food-insecure people rose from 125 million in 1980 to 200 million in 2000 (Molden, 2007). Any strategy to reverse this trend must include agriculture. Kyei-Baffour and Ofori (2006) indicated that in Ghana, economic growth and poverty reduction targets cannot be achieved without significant improvement in the agricultural sector. Agriculture in Ghana has however been challenged by factors such as erratic rainfall patterns, low access to credit, high cost of input, post-harvest losses and poor access to effective markets. These challenges associated with rain-fed agriculture have compelled successive governments to place emphasis on irrigation development.

Crop yields are higher under irrigation due to reliable water supply. Twenty percent of the world's croplands are irrigated, but they produce $40 \%$ of the global harvest, meaning that irrigation more than doubles land productivity (Fernández-Cirelli et al., 2009). Irrigation development will therefore be appropriate to achieve food security, poverty reduction and rural development, more importantly in Northern Ghana which is characterized by unimodal rainfall of short duration and excessive evapotranspiration, allowing only 4 to 5 months of farming and 7 to 8 months of extended dry season (Namara et al., 2011). Since the 1960s, successive Governments in Ghana have made efforts to introduce and promote irrigation through the settlement of a number of small-scale farmers on irrigation facilities in anticipation of the benefits associated with irrigation development. Ghana has a 
potential area of 500000 hectares for irrigation and it has been projected that the total area of irrigation facilities will be increased to 100000 hectares by the year 2020 (Gordon, 2006). United Nation's predictions of global population increase by the year 2025 require an expansion of food production of about $40-45 \%$. Irrigation agriculture will be an essential component of any strategy to increase the global food supply. Irrigation enables small-holder farmers to be able to cultivate high value crops for increased income, increased food production and other socio-economic benefits (Namara et al., 2005). The estimated population of Northern region is 2,468,557 and out of this $1,811,921$ representing $73.4 \%$ of the total population of the region live in rural communities (GSS, 2011). It can therefore be deduced that if irrigation schemes in rural communities perform to their desired results then their impact on socio-economic improvement of the rural folk would be very significant. Addressing water crisis can help reduce extreme poverty and hunger, decrease child morbidity and mortality due to water-related illnesses, help children (especially girls) obtain an education, and promote gender equality (UNDP, 2006). This underscores the significance of sustainable management of water resources in addressing challenges that confront humanity especially vulnerable children and women who are mostly found in rural communities.

Most often, community-based irrigation schemes are established to reduce poverty among rural folks. The establishment of these schemes serves as source of employment and incomes. This is expected to improve the socio-economic conditions of these poor communities. However, information on irrigation schemes in Ghana is scanty, meanwhile it is also reported that deterioration of many schemes have resulted in low efficiency hence productivity of these schemes may be affected (Frenken, 2005). There is the need to appraise and compare schemes to ascertain their current impacts on beneficiaries, and to identify issues regarding the sustainability of these schemes. Irrigation projects like other projects require periodic appraisal of their performance to keep track of the intended purposes so as to derive maximum benefits from them. There have been various appraisal studies of small scale irrigation schemes in parts of Sub-Saharan Africa (Behailu et al., 2005; Dejen et al., 2012). Some of these kinds of studies were also conducted in Northern Ghana (Faulkner et al., 2008; Abdul-Ganiyu et al., 2012a, 2012b), however, as far as we know there has not been much study appraising the Libga and Bunglung schemes. Attaching importance to all small irrigation systems was the new paradigm suggested by Vincent (2003) as part of a comprehensive water management strategy. Due to differences in demographics, human behaviour, soil types, market opportunities and so on, there is the need to appraise each scheme uniquely. This study was conducted to assess the performance of the Libga and Bunglung irrigation schemes by assessing farmers' incomes and crop water productivities, so as to provide on-the-ground information on actual status of the schemes as means of tracking their impacts and progress.

\section{Materials and Method}

\subsection{Description of Study Area}

The study area is in the Savelugu-Nanton District (Figure 1) of Northern Region of Ghana. The District's total land area is $1790.70 \mathrm{~km}^{2}$. The dominant economic sector is agriculture. Agriculture engages about 97 percent of the labour force, with majority producing staple crops at subsistence level (Savelugu Nanton District Assembly, 2012). Cash crop production is very minimal and this includes sheanut, Soy beans, cotton and cashew. Major economic activities in the district include: agriculture, trading in foodstuff such as maize, beans, rice and other grains, sand winning, fishing and sheanut processing. Like most communities in Northern Ghana, income levels and economic status are generally low especially among women. Majority of the people depend on rainfed agriculture, however there are a few small scale irrigation schemes.

\subsection{Description of Libga Irrigation Scheme}

Libga is a community located about $4 \mathrm{~km}$ away from Savelugu, the district capital of the Savelugu-Nanton district. The geographical co-ordinates is $9^{\circ} 35^{\prime} \mathrm{N}, 0^{\circ} 51^{\prime} \mathrm{W}$. The Libga irrigation scheme is found in the Libga community but provides services to about 6 communities including Libga, Savelugu, Zazzi, Nyoglo, Kanshegu and Behenayili (Adongo, 2015). The Libga reservoir was completed in 1971 and rehabilitation works were carried out in 1984, 2005 and 2008 respectively. The reservoir has a storage capacity of $5.9 \mathrm{Mm}^{3}$, a potential irrigable area of 40 hectares but a developed area of 20 hectares (Asante, 2009). The Libga scheme is one of 22 formal schemes managed by the Ghana Irrigation Development Authority (GIDA). Major crops cultivated in the scheme include rice, onion, leafy vegetables and maize. GIDA oversees the overall management of the scheme including rehabilitation of the infrastructure such as the dam wall maintenance, reservoir desilting, canal construction, spillway construction, etc. It is also responsible for planning, organisation of farmer groups, technical training, water distribution schedules and conflict resolution. The water users association (WUA) is responsible for operation and minor maintenance of the scheme. The WUA in this scheme is made up of 41 registered members. However there are many non-registered members cultivating in the scheme. 


\subsection{Description of Bunglung Irrigation Scheme}

Bunglung is a small community found in the Savelugu-Nanton district. The geographical coordinates is $9^{\circ} 36^{\prime} 0^{\prime \prime}$ $\mathrm{N}, 0^{\circ} 48^{\prime} 0^{\prime \prime} \mathrm{W}$. It is about $5 \mathrm{~km}$ east of the Tamale-Bolgatanga road from Savelugu. The Bunglung irrigation scheme is not one of the 22 formal irrigation schemes managed by GIDA. It is jointly managed by an Agricultural Extension Agent (AEA) on behalf of Ministry of Food and Agriculture (MoFA) and the community. However GIDA was consulted to provide consultancy services during its rehabilitation in 2008 by MoFA. Rehabilitation works that took place included desilting of the reservoir and rehabilitation of the canals. A water bailiff who is also a farmer in the irrigation system manages the outflow of water into the canals and distribution to various farms is ensured by the WUA. Farmers from Savelugu, Bunglung and surrounding communities use water from the reservoir for dry season farming, domestic use and livestock watering (Yussif, 2012).

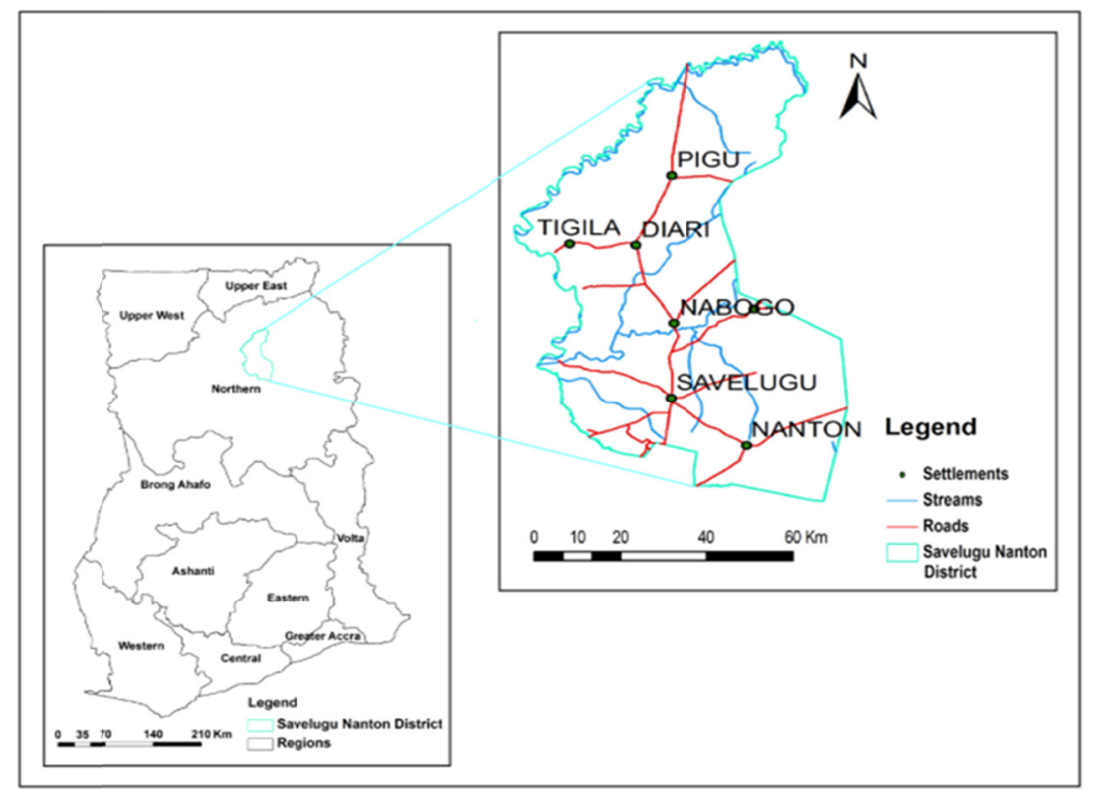

Figure 1. Map of Ghana showing Savelugu-Nanton District

\subsection{Data Sources and Collection Procedure}

Libga and Bunglung irrigation schemes were selected to be investigated. Sixty households were selected using random sampling techniques from each scheme. The gathered information from farmers included their production activities between 2013 and 2015. Table 1 indicates the demographic characteristics of sampled respondents in this study.

Table 1. Gender and age distribution of farmers

\begin{tabular}{llc}
\hline \multirow{2}{*}{ Demographic factor } & \multicolumn{2}{c}{ Frequency/Percent } \\
\cline { 2 - 3 } & Libga & Bunglung \\
\hline Gender & 40 & 37 \\
Male & 20 & 23 \\
Female & 60 & 60 \\
Total & & \\
\hdashline Age & 8.3 & 10.5 \\
$18-29$ & 53.3 & 51.2 \\
$30-45$ & 31.7 & 26.8 \\
$46-60$ & 6.7 & 11.5 \\
$>60$ & 100 & 100 \\
Total & &
\end{tabular}


A structured questionnaire was used to collect data from sampled households. Yield, production cost, market prices and revenue data were gathered from the farmers. Yield figures were also confirmed by taking samples from farmers' fields in various irrigation laterals and measuring in-situ. Most farmers reported yields in bags/acre. These were then converted to tons per hectare. For the rainfed systems, secondary data on crop prices and yields of crops in the district were obtained from Statistics, Research and Information Department (SRID) of MoFA. Two crops were selected: rice (Oryza sativa) and pepper (Capsicum frutescens), to assess farmers' profitability and water productivities under irrigation. Rice was selected because it is the main crop grown in most formal irrigation schemes in Ghana especially in the rainy season, while pepper was selected as representative for high valued vegetables which is also mostly grown in the dry season. These 2 crops were the most widely cultivated as well in these schemes as shown in Figure 2. Cost Benefit Analysis was conducted by analyzing net income expressed as total revenue from crops harvested less production cost (Etwire et al., 2018), and represented mathematically by Equation 1. Benefit/Cost ratio (Equation 2), was also used to evaluate the ratio of net benefit to production cost.

$$
\begin{gathered}
\text { Net Income }=\text { Gross return on investment }- \text { Average variable cost } \\
\qquad \text { Benefit-Cost ratio }=\frac{\sum \mathrm{B}}{\sum \mathrm{C}}
\end{gathered}
$$

Where, $\mathrm{B}=$ Average net revenue per acre $\mathrm{C}=$ Average production cost per acre.

Crop water productivity was calculated as expressed in Equation 3 (Molden, 1997; Ahmad et al., 2004; Rashidi \& Gholami, 2008):

$$
\mathrm{CWP}=\mathrm{C} \frac{\mathrm{Y}}{\mathrm{ET}}
$$

Where, CWP is the crop water productivity $\left(\mathrm{kg} / \mathrm{m}^{3}\right)$; $\mathrm{Y}$ is the actual yield $(\mathrm{kg} / \mathrm{ha})$; ET is the evapotranspiration or crop water requirement $(\mathrm{mm})$; $\mathrm{C}$ is a conversion factor of 0.1 .

CropWat Model (version 8), was used to calculate the crop water requirements for rice and pepper cultivation, which were then used as the evapotranspiration (ET) in this study. CropWat is a computer program developed by Land and Water division of FAO for calculation of crop water and irrigation requirements using climatic, crop, and soil data (Smith, 2001). Climatic data of Tamale was obtained from Climwat software, version 2.0 which contains long term agroclimatic data (1971-2000) of over 5000 stations worldwide (Muñoz \& Grieser, 2006), which is also developed by the Water Development and Management Unit and the Climate Change and Bioenergy Unit of FAO. Soil texture, field capacity, permanent wilting point and soil saturation water content were obtained by taken soil samples for analysis in the laboratory. Infiltration rate was measured in-situ by the double ring infiltrometer method (Haise et al., 1956). These were inputted into the CropWat software for estimation of ET.

The gross value of production per unit water consumed, expressed as economic water productivity (EWP) was calculated by equation 4 as modified from Molden et al. (1998).

$$
\mathrm{EWP}=\frac{\mathrm{Y} \times \mathrm{P}}{\mathrm{ET}}=\mathrm{CWP} \times \mathrm{P}
$$

Where, EWP is the economic water productivity in Ghana cedis per cubic meter $\left(\mathrm{GH} \phi / \mathrm{m}^{3}\right) ; \mathrm{P}=$ Local price of the crop per kilogram in Ghana cedis $(\mathrm{GH} \phi / \mathrm{kg})$.

\subsection{Statistical Analysis}

The Statistical Package for Social Scientist (SPSS) version 19 (IBM Corporation, Chicago, USA) and Microsoft excel (2007) were used to analyze the data. Frequency counts and percentages of demographic data, crops produced in each scheme and farmers' perceptions on impact of irrigation on household incomes were analyzed while averages and standard errors of production cost, average yield per acre, average prices of crops and revenue were also analyzed. Regression analysis was also conducted to establish the relationship between crop yield and revenue. Means of yield for rice between the two irrigations schemes and the traditional system were separated at $95 \%$ confidence interval using the Duncans multiple range tests.

\section{Results}

\subsection{Crops Cultivated and Crop Yields in the Schemes}

Majority of farmers at the Bunglung scheme cultivated pepper whilst some farmers cultivated tomato during the dry season as well as rice and maize during the rainy season. Farmers at Libga cultivated leafy vegetables, pepper and onions during the dry season but planted rice in the rainy season (Figure 2). Average yields of rice at Libga and Bunglung were 3.9 ton per hectare and 4.5 ton per hectare respectively while yield in the traditional 
rainfed system was 2.9 ton per hectare (Figure 3). Average yield of pepper in Libga was 4.0 ton per hectare while that of Bunglung was 3.4 ton per hectare (Figure 3).

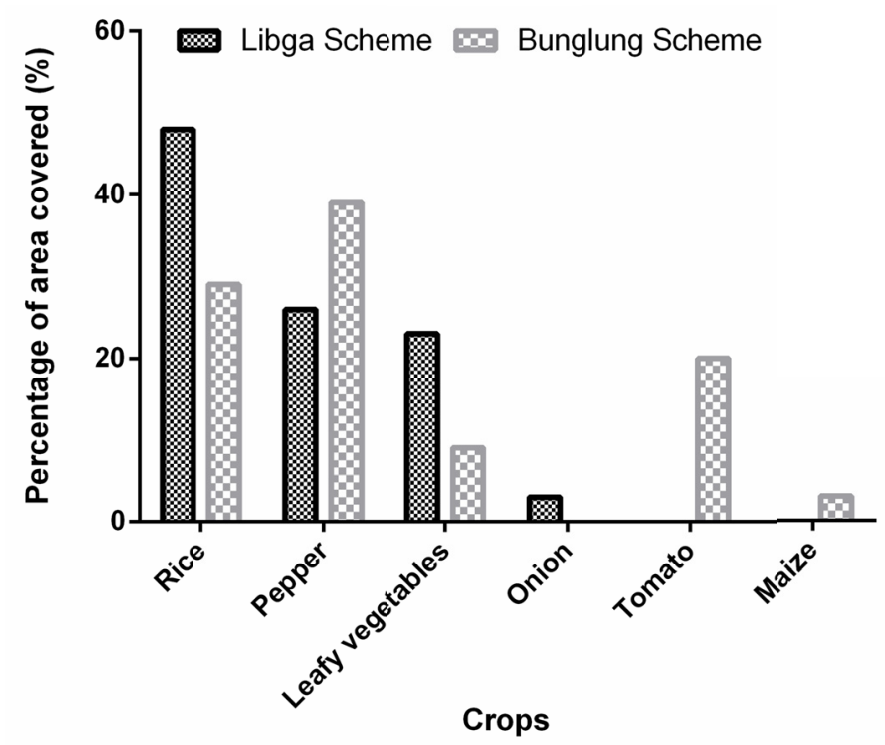

Figure 2. Crops grown at Libga and Bunglung Schemes by percentage of area covered (2013-2015)

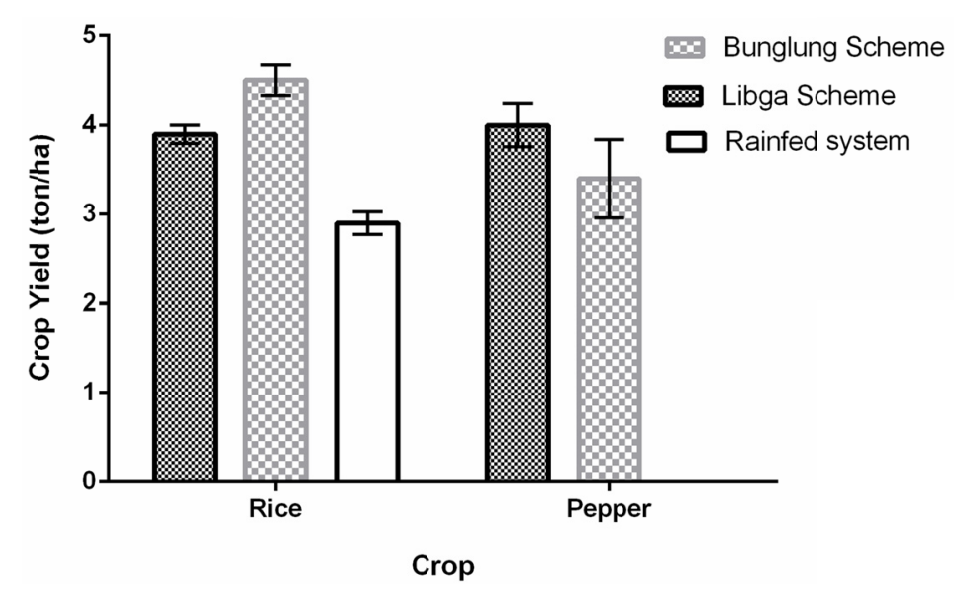

Figure 3. Average yield of rice and pepper in Libga and Bunglung schemes (2013-2015)

Note. Error bars represent standard error of the mean.

\subsection{Household Incomes in the Irrigation Schemes}

Farmers in Bunglung community invested an average amount of 310.00 Ghana cedis (Figure 4a) and accrued revenue of 1260.00 Ghana cedis, therefore making a profit of 950.00 Ghana cedis annually from rice only (Table 2). In a similar trend, farmers in Libga invested an average amount of 464.00 Ghana cedis and accrued revenue of 1184.00 Ghana cedis therefore making a net profit of 720.00 Ghana cedis. Rice production had benefit-cost ratio of 2.6 and 4.1 for Libga and Bunglung respectively.

The average cost of pepper production per acre was 553.2 and 320.5 Ghana cedis in Libga and Bunglung schemes respectively (Figure $4 \mathrm{~b}$ ). These resulted in average revenue of 2640.0 Ghana cedis in Libga scheme and 2250.00 Ghana cedis in Bunglung scheme, amounting to net income of 2087.00 and 1929.50 Ghana cedis respectively (Table 3). Pepper production had a benefit-cost ratio of 4.8 for Libga and 7.0 for Bunglung. 
(a)

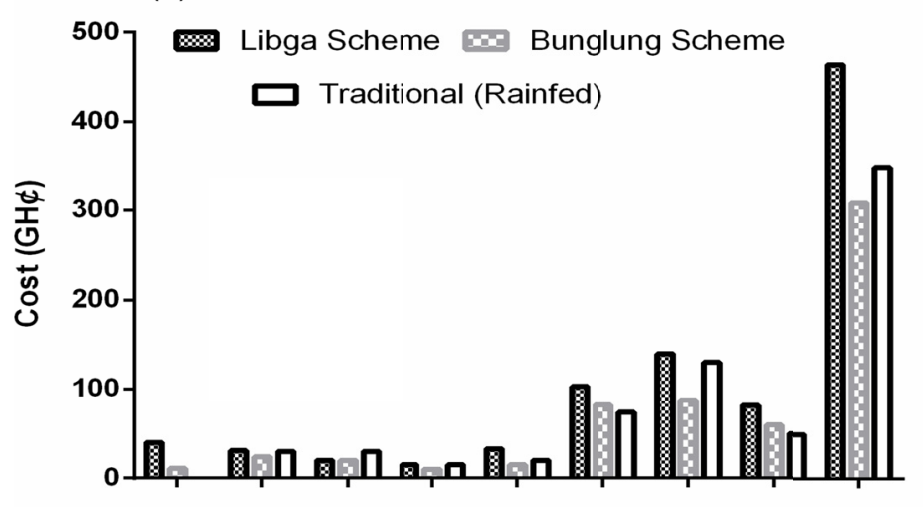

(b)

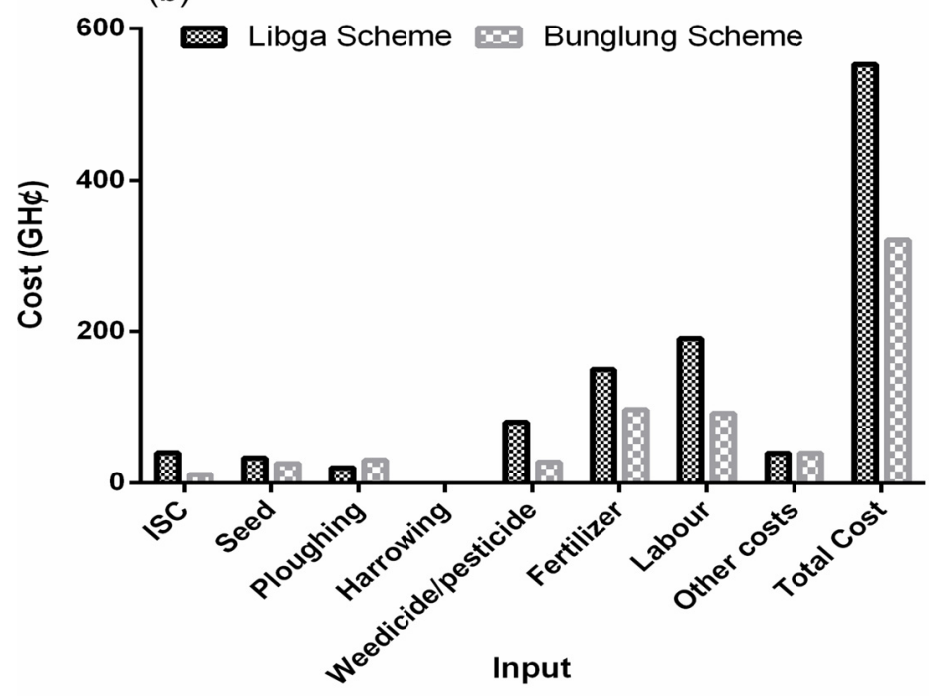

Figure 4. Cost of production for rice (a) and pepper (b) at the Libga and Bunglung irrigation schemes Note. ISC means irrigation service charge.

Table 2. Net income on investment and benefit-cost ratio (Rice)

\begin{tabular}{lllll}
\hline Project Site & $\begin{array}{l}\text { Total Variable Cost } \\
\text { Per Acre }(\mathrm{GH} \phi)\end{array}$ & $\begin{array}{l}\text { Gross Return On } \\
\text { Investment/Acre }(\mathrm{GH} \phi)\end{array}$ & Net Income/Acre $(\mathrm{GH} \phi)$ & Benefit-Cost Ratio \\
\hline Libga Scheme & $464.0(23.06)$ & $1184.0(18.9)$ & $720.0(18.67)$ & 2.6 \\
Bunglung Scheme & $310.0(4.25)$ & $1260(21.29)$ & $950.0(22.79)$ & 4.1 \\
Traditional (Rainfed) & 349.0 & 720.0 & 371.0 & 2.1 \\
\hline
\end{tabular}

Note. Values in brackets are standard errors of the mean.

Ghana cedis $(\mathrm{GH} \phi)$ is the currency of Ghana. The rate in 2013 was $1 \mathrm{GH} \phi=\$ 0.42$.

Table 3. Net income on investment and benefit-cost ratio (Pepper)

\begin{tabular}{lllll}
\hline Project Site & $\begin{array}{l}\text { Total Variable Cost } \\
\text { Per Acre }(\mathrm{GH} \phi)\end{array}$ & $\begin{array}{l}\text { Gross Return On } \\
\text { Investment/Acre }(\mathrm{GH} \phi)\end{array}$ & Net Income/Acre (GH $\dot{\text { B }})$ & Benefit-Cost Ratio \\
\hline Libga Scheme & $553.2(20.97)$ & 2640.0 & $2087.0(75.76)$ & 4.8 \\
Bunglung Scheme & $320.5(11.85)$ & 2250.0 & $1929.5(127.64)$ & 7.0 \\
\hline
\end{tabular}

Note. Values in brackets are standard errors of the mean. 
Farmers perception were surveyed about whether their income levels had increased since they joined the schemes, and the results indicated that $70.0 \%$ of Libga farmers strongly agreed that their incomes had increased, 26.7\% agreed while only 3.3\% disagreed. Response from Bunglung farmers indicated that $83.3 \%$ strongly agreed that their household incomes had increased whilst $16.7 \%$ agreed that their incomes had increased since they joined the scheme (Figure 5).

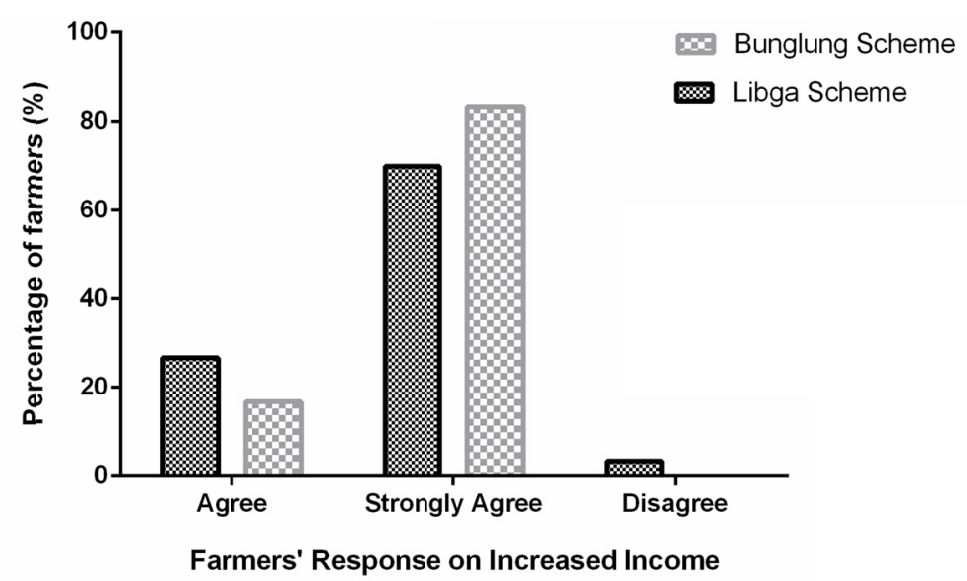

Figure 5. Farmers' perception on increased household income

\subsection{Water Productivity}

Crop water requirement of rice in the Libga scheme was $746.7 \mathrm{~mm}$ while that of pepper was $527.4 \mathrm{~mm}$. The CWP for rice was 0.50 kilogram per cubic meter at the Libga scheme and 0.58 kilogram per cubic meter at the Bunglung scheme. In monetary terms, the gross value per unit water required for rice were 0.38 and $0.41 \mathrm{Ghana}$ cedi per cubic meter respectively as shown in Table 4. The CWP of pepper for the Libga and Bunglung schemes were 0.74 and 0.64 kilogram per cubic meter respectively while gross value per unit water required was 1.23 and 1.07 Ghana cedi per cubic meter respectively (Table 4). Comparison between water productivity of rice and pepper in Libga and Bunglung Schemes showed that water productivity of rice was greater in Bunglung while that of pepper was greater in Libga.

Table 4. Water productivity in terms of crop yield and gross value of production

\begin{tabular}{llllll}
\hline \multirow{2}{*}{ Scheme } & \multicolumn{2}{c}{$\mathrm{CWP}\left(\mathrm{kg} / \mathrm{m}^{3}\right)$} & & \multicolumn{2}{c}{$\mathrm{CWP}\left(\mathrm{GH} \phi / \mathrm{m}^{3}\right)$} \\
\cline { 2 - 3 } \cline { 5 - 6 } & Rice & Pepper & & Rice & Pepper \\
\hline Libga & 0.50 & 0.74 & & 0.38 & 1.23 \\
Bunglung & 0.58 & 0.64 & & 0.41 & 1.07 \\
\hline
\end{tabular}

Note. CWP means crop water productivity, $\mathrm{kg} / \mathrm{m}^{3}$ means kilogram per cubic meter while $\mathrm{GH} \notin / \mathrm{m}^{3}$ means $\mathrm{G} h a n a$ cedis per cubic meter.

\subsection{Effect of Yield on Farmer Revenue}

Figure 6 shows regression analysis between crop yield and revenue. There was significant correlation $(\mathrm{p}<$ 0.0001 ) between crop yield and revenue for both rice and pepper production. Yield considered as a sole factor accounted for $64.52 \%$ of variations in gross revenue in rice cultivation and $98.36 \%$ of gross revenue variations in pepper cultivation. 
(a)

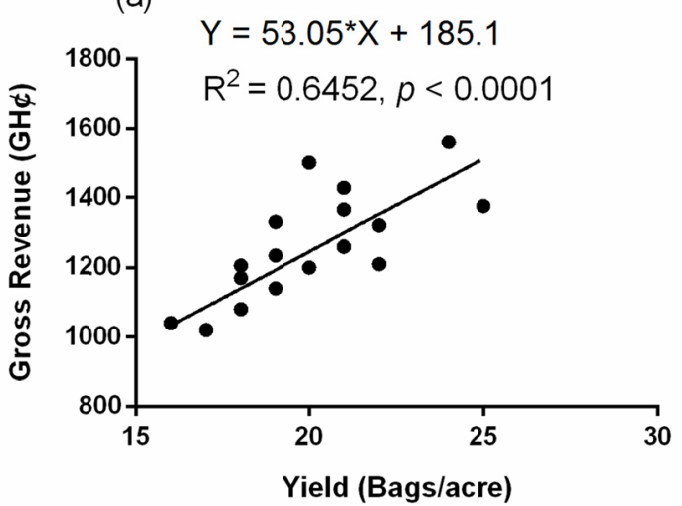

(b)

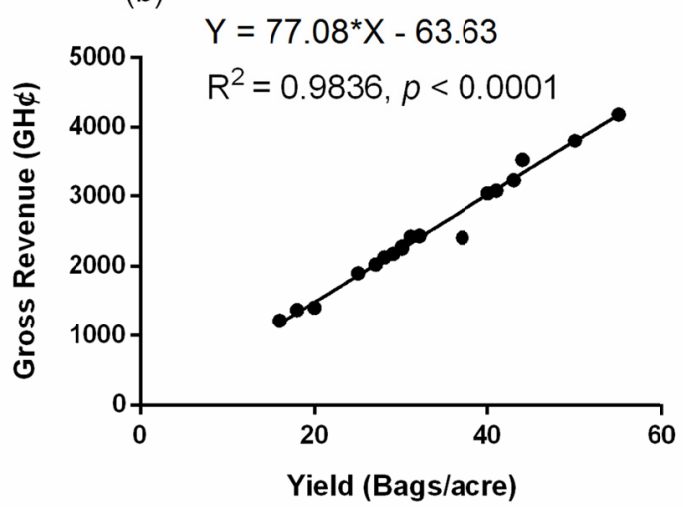

Figure 6. Regression analysis between average yield within an irrigation lateral (Bags/acre) and average revenue $(\mathrm{GH} \phi)$ for rice (a) and pepper (b)

Note. A bag of rice weighed $85 \mathrm{~kg} / \mathrm{bag}$ while a bag of pepper weighed $45 \mathrm{~kg} / \mathrm{bag}$ at both schemes.

\section{Discussion}

Compared to the traditional rainfed practice in the district, rice yields under irrigation increased (Figure 3). So an increase in food availability and accessibility in both Libga and Bunglung is expected. Cultivation of fresh vegetables in the schemes will also increase access to nutritious meals by households within these communities thereby improving the food security condition of the rural folk. Farmers are also able to meet their consumption demand and sell the surplus to earn income. Irrigation has been shown to have a strong positive relationship with poverty alleviation and food security (Dixon et al., 2001). In India irrigation districts had their poverty levels reduced significantly compared to non-irrigated districts (Beero \& Narayanamoorthy, 2014). Yields obtained in this study for pepper and rice were within range of irrigated rice yields reported in a nearby district (Abdul-Ganiyu et al., 2012a, 2012b). Rice yields as reported in this study have increased, compared to traditional practices, yet there exists the potential to make higher gains if farmers improved management activities. As high as 7.0 ton per hectare could be obtained under irrigation but low investments, bird attacks, and poor management practices often lead to moderate gains (Abdul-Ganiyu et al., 2012a). Similarly, pepper yields in this study (3.4 4.0 ton per hectare) were far lower than those reported by FAO (2010) from commercial farms, which were in the range of 10-25 ton per hectare. This indicates that the level of commercialisation by farmers in our study area is still very low. Lower investments in general and low use of inputs specifically, which characterises non-commercial oriented producers may result in lower yields, hence low incomes.

Variation in net income for rice production between Bunglung and Libga could be due to significant greater yields in Bunglung of 4.5 ton per hectare compared to 3.9 ton per hectare in Libga $(\mathrm{p}<0.05)$ (Figure 3). Higher yields may result in higher revenue. This is evident by the fact that, in this study, we found highly significant positive correlation $(\mathrm{p}<0.0001)$ between average crop yield of an irrigation lateral and revenue accrued for both rice and pepper (Figure 6). The regression analysis indicated that considering yield only as a factor, it accounted for 98.36 and $64.52 \%$ of variations in revenue from pepper and rice production respectively. Another factor which might contribute to the profit variation is lower amounts charged for water use per acre at Bunglung (11.0 Ghana cedis) which reduces the production cost for Bunglung farmers as compared to 40.00 Ghana cedis paid by Libga farmers per acre (Figure 4). Farmers in Libga also spent more on inputs than farmers in Bunglung to sustain the fertility of soils which have been cultivated over and over for several years. This, together with relatively higher labour cost in Libga (Figure 4) increased their cost of production. Production costs incurred by farmers played influencing role on the profits they made (Faulkner et al., 2008). During focus group discussions with Libga farmers, they indicated that, continuous cropping of the Libga soils since its construction in 1969 may have caused a reduction of its soil fertility. However, using net income, pepper production was more profitable in Libga than in Bunglung. High investment due to relative high input use increased the yield of pepper in Libga resulting in greater profit margins while lower investment by farmers in Bunglung scheme (Figure 4) resulted in relatively lower pepper yields. The use of other inputs such as improved seeds and fertilizer could maximise benefits from irrigation. Reliable water supply from irrigation, coupled with high yielding varieties and optimum fertilizer use accelerated the contribution of irrigation to food production 
between 1966 and 1990 (IWMI, 2000). Comparing profitability of crops, pepper production was more profitable than rice in both schemes (Table 4). This could be attributed to the fact that vegetables usually have higher prices than grain crops.

The crop water requirement of rice $(746.7 \mathrm{~mm})$ in this study was lower than reported by Abdul-Ganiyu et al. (2012b) in their study in the Bontanga irrigation scheme in the Northern region $(939.9 \mathrm{~mm})$. Our result of water requirement for pepper were in line with findings by Agodzo et al. (2003) that, for vegetable crops, the requirements of water by the crops will range between $300-700 \mathrm{~mm}$ depending on the climatic condition, the season of the crop and the location. The variation in water requirement of rice in this study and that of Abdul-Ganiyu et al (2012b) could also be attributed to difference in soil properties and seasons as indicated by Agodzo et al (2003). Furthermore, the seasonal crop water need is also influenced by the growing season (Brouwer et al., 1985).

Water productivities varied between the schemes studied and these arose due to yield differences. Due to the higher yield of rice in Bunglung, water productivity of rice was higher in Bunglung compared to that of Libga while higher pepper yield in Libga also resulted in higher water productivity for pepper in Libga. Using average dollar rate of 1 United States Dollars $=2.4$ Ghana cedis in 2013 (http://www.freecurrencyrates.com/ exchange-rate-history/USD-GHS/2013), the gross value in terms of crop water required for rice in this study were 0.16 and 0.17 United States Dollars per cubic meter for Libga and Bunglung respectively whilst that of pepper were 0.51 and 0.45 United States Dollars per cubic meter respectively. These were in line with other studies. Molden et al. (1998) in a study in Burkina Faso and Niger, reported water productivities ranging between 0.11 and 0.91 United States Dollars per cubic meter. Dejen et al., (2012) also showed output per unit water consumed ranging between 0.33 and 0.48 United States Dollars per cubic meter in their assessment of performance of irrigation systems in Ethiopia. In both Libga and Bunglung, pepper production was more economical in terms of water saving than rice production. This could be attributed to the high yield and price of pepper compared to rice production. More so, crop water requirement for rice was much higher than that of pepper.

\section{Conclusion}

The results of the study revealed that pepper production had higher returns and greater water productivity compared to rice in both schemes although irrigation generally improved farmer's incomes. The results also showed that rice production under irrigation yielded more crop per land compared to traditional rainfed systems in the area. Irrigation holds a huge potential of improving farmers' profitability and socioeconomic conditions through increased yields. However, the level of commercialisation of farmers in the study area is still low and is characterised by low input use. Farmers should invest more in maintaining or improving their soil fertility through increased use of both organic and inorganic fertilizers, pesticides and improved seeds in order to reduce the current yield gap.

\section{Acknowledgements}

The research is financed by the Department of Science and Technology of Gansu Province, China (1504NKCA029).

\section{References}

Abdul-Ganiyu, S., Amaanatu, M. K., \& Korese J. K. (2012a). Crop water use and productivity for pepper (capsicum frutescens) production in the Bontanga irrigation scheme of northern region of Ghana. International Journal of Agricultural Science and Bioresource Engineering Research, 1(2), 43-50.

Abdul-Ganiyu, S., Amaanatu, M. K., \& Korese, J. K. (2012b). Water use efficiency and productivity for rice (Oryza sativa) in the Bontanga irrigation scheme of northern region of Ghana. Agricultural Science Research Journals, 2(7), 362-368.

Adongo, T. A. (2015). Performance assessment of irrigation schemes in northern Ghana using comparative performance indicators (Master's Thesis, University for Development Studies, Tamale, Ghana).

Agodzo, S. K., Huibers, F. P., Chenini, F., van Lier, J. B., \& Duran, A. (2003). Use of waste water in irrigated agriculture; country studies from Bolivia, Ghana and Tunisia (Volume 2: Ghana). Wageningen: WUR.

Ahmad, M. D., Masih, I., \& Turral, H. (2004). Diagnostic Analysis of Spatial and Temporal Variations in crop Water Productivity: A Field Scale Analysis of the Rice-Wheat Cropping System of Punjab. Pakistan Journal of Application Irrigation Science, 1, 43-63. 
Asante, F. (2009). Rethinking water storage for climate change adaptation in sub-Saharan Africa. Technical, economic and financial performance in Volta basin. In R. Johnston, \& M. McCartney (Eds.), Inventory of Water Storage Types in the Blue Nile and Volta River Basins (Working Paper 140). International Water Management Institute (IWMI), Colombo, Sri Lanka. https://doi.org/10.5337/2010.214

Beero, S. K., \& Narayanamoorthy, A. (2014). Rural Poverty and Irrigation Performance in India: A District-level Study. International Journal of Social Science, 3(3), 329. https://doi.org/10.5958/2321-5771.2014.00008.8

Behailu, M., Abdulkadir, M., Mezgebu, A., \& Yasin, M. (2005). Report on Community Based Irrigation Management in the Tekeze Basin: Performance Evaluation. A Case Study on Three Small-scale Irrigation Schemes.

Brouwer, C., Goffeau, A., \& Heibloem, M. (1985). Irrigation Water Management: Training Manual No. 1-Introduction to Irrigation. Rome, Italy: Food and Agriculture Organization of the United Nations.

Dejen, Z. A., Schultz, B., \& Hayde, L. (2012). Comparative irrigation performance assessment in community-managed schemes in Ethiopia. African Journal of Agricultural Research, 7, 4956-4970.

Dixon, J., Gulliver, A., \& Gibbon, D. (2001). Farming System and Poverty: Improving Farmers' Livelihoods in a Changing World. Rome and Washington, DC: FAO and the World Bank.

Etwire, P. M., Fielding, D., \& Kahui, V. (2018). Climate Change, Crop Selection and Agricultural Revenue in Ghana: A Structural Ricardian Analysis. Journal of Agricultural Economics. https://doi.org/10.1111/ 1477-9552.12307

Faulkner, J. W., Steenhuis, T., van de Giesen, N., Andreini, M., \& Liebe, J. R. (2008). Water use and productivity of two small reservoir irrigation schemes in Ghana's Upper East Region. Irrigation and Drainage: The Journal of the International Commission on Irrigation and Drainage, 57(2), 151-163. https://doi.org/ 10.1002/ird.384

Fernández-Cirelli, A., Arumí, J. L., Rivera, D., \& Boochs, P. W. (2009). Environmental effects of irrigation in arid and semi-arid regions. Chilean Journal of Agricultural Research, 69(Suppl. 1), 27-40. https://doi.org/ $10.4067 / \mathrm{S} 0718-58392009000500004$

Food and Agriculture Organization. (2010). Crop Water Information: Pepper. FAO Water Development and Management Unit, Food and Agriculture Organization (FAO) of UN, Rome. Retrieved from http://www.fao.org/copyright_en.htm

Frenken, K. (2005). Irrigation in Africa in figures: AQUASTAT Survey, 2005 (Vol. 29). Food and Agriculture Organization (FAO).

Ghana Statistical Service. (2011). Ghana's Economic Performance 2010 in Figures. Accra, Ghana: Ghana Statistical Service.

Gordon, C. (2006). Background Paper for the Multi-stakeholder consultation process for Dams Development in Ghana (pp. 12-36). Volta Basin Research Project, University of Ghana.

IWMI (International Water Management Institute). (2000). Water for Food, Nature and Rural Livelihoods. Colombo, International Water Management Institute (IWMI).

Kyei-Baffour, N., \& Ofori, E. (2006). Irrigation development and management in Ghana: Prospects and challenges. Journal of Science and Technology (Ghana), 26(2), 148-159. https://doi.org/10.4314/just.v26 i2.32996

Molden, D. (2007). Water for Food, Water for Life: A Comprehensive Assessment of Water Management in Agriculture. London: Earthscan, and Colombo: International Water Management Institute (IWMI). https://doi.org/10.4324/9781849773799

Molden, D. J. (1997). Accounting for water use and productivity, SWIM Paper 1, system-wide initiative for water management (Vol. 1, p. 16). Colombo, Sri Lanka: International Water Management Institute (IWMI).

Molden, D. J., Sakthivadivel, R., Perry, C. J., \& de Fraiture, C. (1998). Indicators for comparing performance of irrigated agricultural systems. International Water Management Institute (IWMI) Research Report.

Muñoz, G., \& Grieser, J. (2006). Climwat 2.0 for CROPWAT. Rome, Italy: Food and Agriculture Organization (FAO). 
Namara, R. E., Horowitz, L., Nyamadi, B., \& Barry, B. (2011). Irrigation Development in Ghana: Past experiences, emerging opportunities, and future directions. Ghana Strategy Support Program (GSSP) Working Paper 27. International Food Policy Research Institute (IFPRI).

Namara, R., Upadhyay, B., \& Nagar, R. K. (2005). Adoption and impacts of microirrigation technologies: Empirical results from selected localities of Maharashtra and Gujarat States of India (Vol. 93). International Water Management Institute (IWMI).

Rashidi, M., \& Gholami, M. (2008). Review of Crop Water Productivity values for Tomato, Melon, Watermelon and Cantaloupe in Iran. International Journal of Agriculture and Biology, 10, 432-6.

Savelugu Nanton District Assembly. (2012). Composite Budget of the Savelugu Nanton District Assembly for the Fiscal Year, 2012. Ghana: Savelugu Nanton District Assembly.

Smith, M. (1992). CROPWAT: A computer program for irrigation planning and management (No. 46). Food and Agriculture Organization.

UNDP (United Nations Development Program). (2006). Human Development Report 2006: Beyond Scarcity-Power, Poverty and the Global Water Crises. New York: UNDP. https://doi.org/10.18356/ 334 c604b-en

Vincent, L. F. (2003). Towards a smallholder hydrology for equitable and sustainable water management. Natural Resources Forum (Vol. 27, No. 2, pp. 108-116). Oxford, UK: Blackwell Publishing Ltd. https://doi.org/10.1111/1477-8947.00046

Yussif, S. (2012). Assessment of Water Sources in Terms of Availability, Use and Sufficiency in the Northern Region of Ghana (Doctoral dissertation, Kwame Nkrumah University of Science and Technology, Kumasi, Ghana). Retrieved from http://ir.knust.edu.gh/bitstream/123456789/5893/2/Main\%20work.pdf

\section{Copyrights}

Copyright for this article is retained by the author(s), with first publication rights granted to the journal.

This is an open-access article distributed under the terms and conditions of the Creative Commons Attribution license (http://creativecommons.org/licenses/by/4.0/). 